\title{
PENERAPAN MODEL PEMBELAJARAN MODELLING THE WAY UNTUK MENINGKATKAN HASIL BELAJAR SISWA MEMBUAT BONEKA DARI KAIN FLANEL PADA MATA PELAJARAN PRAKARYA DI KELAS X SMA SULTAN ISKANDAR MUDA MEDAN
}

\author{
Henni Siswanti Panjaitan dan Armaini Rambe \\ Jurusan PKK Program Studi PKK \\ Fakultas Teknik Universitas Negeri Medan
}

\begin{abstract}
ABSTRAK
Penelitian ini bertujuan untuk mengetahui hasil belajar siswa membuat boneka dari kain flanel dengan menerapkan model pembelajaran Modelling The Way pada mata pelajaran siswa kelas X- IPS SMA Sultan Iskandar Muda dan untuk mengetahui pengaruh hasil belajar dengan menggunakan model pembelajaran Modeling The way pada siswa kelas X - IPS SMA Sultan Iskandar Muda. Sabjek dalam penelitian ini adalah siswa kelas X-IPS Sultan Iskandar Muda sebanyak 34 orang. Jenis penelitian adalah penelitian tindakan kelas (PTK) yang dikemukakan oleh Arikunto Strategi ini mempunyai empat tahapan, yaitu tahap: (1) perencanaan, (2) pelaksanaan, (3) pengamatan, dan (4) refleksi yang terdiri dari dari dua siklus.Berdasarkan uji kesepakatan pengamat menggunakan analisis varian satu arah dengan tarif signifikan 5\%, Irianto (2010).hasil ANAVA (F hitung ) dikonsultasikan dengan $\mathrm{F}$ tabel dengan taraf signifikan $5 \%$ bila $\mathrm{F}$ hitung < $\mathrm{F}$ table $5 \%$ maka disimpulkan tidak ada perbedaan hasil penilaian dali lima pengamat, sehingga lembar pengamat dapat digunakan untuk menjaring data penilaian .Diperoleh ketuntasan belajar siswa sebesar 85,30\% dari 34 orang siswa memperoleh peningkatan hasil belajar sebesar 40,30\% dari hasil belajar sebelumnya. Dan rata rata aktivitas siswa pada siklus I berada pada kriteria aktif $(51,43 \%)$ dari 18 orang siswa dari 34 orang siswa. Sehingga tidak perlu dilakukan siklus ke II karena hasil belajar siswa secara klasikal sekurang kurangnya $75 \%$ siswa memperoleh nilai $\geq 75$ sesuai dengan kriteria ketuntasan minimal (KKM) mata pelajaran prakarya membuat boneka dari kain flanel dan berdasarkan siklus I yang telah dilakukan maka dapat dikatakan berhasil karena hasil belajar siswa meningkat Hasil penelitian menyimpulkan bahwa Penerapan Model Pembelajaran Modelling The way dapat meningkatkan hasil belajar siswa kelas X IPS SMA Sultan Iskandar Muda terutama dalam mata pelajaran prakarya dan kewirausahaan dengan kopetensi dasar mebuat boneka dari kain flanel.
\end{abstract}

Kata Kunci: Model Pembelajaran Modelling The Way, Hasil Pembelajaran

\section{PENDAHULUAN}

Pendidikan harus dirancang dan dilaksanakan selaras dengan kebutuhan yang berkembang pada masyarakat, untuk mensukseskan pembangunan tersebut dibutuhkan sumber daya manusia (SDM) yang memiliki kemampuan untuk menguasai ilmu pengetahuan dan teknologi (IPTEK) yang cukup tinggi serta di barengi dengan keterampilan pendidikan dan tenaga kerja yang mempunyai hubungan yang erat. Lembaga pendidikan mempunyai tanggung jawab untuk menciptakan sumber daya manusia yang mempunyai kualitas dengan cara mempersiapkan lulusan yang mampu mengikuti dan mengisi laju perkembangan ilmu pengetahuan dan teknologi.
Kurikulum merupakan seperangkat rencana dan pengaturan mengenai tujuan, isi, dan bahan pelajaran serta cara yang digunakan sebagai pedoman penyelenggaraan kegiatan pembelajaran untuk mencapai tujuan pendidikan tertentu. Menurut Hamalik, (2008) kurikulum merupakan suatu program pendidikan yang disediakan untuk membelajarkan siswa, dengan program itu para siswa melakukan berbagai kegiatan belajar, sehingga terjadi perubahan dan perkembangan tingkah laku siswa, sesuai dengan tujuan pendidikan dan pembelajaran. Sekolah Iskandar Muda mengelola jenjang pendidikan mulai dari TK, SD, SMP, dan SMA, SMK Sekolah Iskandar Muda mempersiapkan siswa lulusannya memiliki daya kreatifitas yang tinggi 
sehingga siswa mempunyai sikap dan kepekaan untuk lebih menghargai hasil keterampilan tangan, oleh sebab itu didalam kurikulum 2013 yang digunakan oleh sekolah SMA Sultan Iskndar Muda, terdapat mata pelajaran prakarya.

Berdasarkan hasil observasi yang dilakukan di sekolah SMA Sultan Iskandar Muda Selama proses pembelajaran mata pelajaran prakarya dan kewirausahaan guru kurang menvariasikan model pembelajaran yang dibarengi dengan metode ceramah. Pada saat pembelajaran berlangsung, guru menjelaskan suatu produk yang akan di selesaikan dan selama proses belajar guru lebih banyak memberi informasi - informasi sedangkan siswa hanya sebagai pendengar, dan sibuk dengan aktivitas masing - masing, sehingga siswa kurang aktif, kurang dapat memahami pelajaran, siswa merasa bosan mengikuti pembelajaran, dalam hal ini peserta didik akan merasakan situasi yang membosankan karena guru lebih banyak berperan dalam proses belajar mengajar, penulis menduga model pembelajaran ini kurang efektif digunakan pada mata pelajaran prakarya karna bersifat satu arah dan berpusat pada guru. Hal ini mempengaruhi hasil belajar siswa 2 tahun terakhir kurang meningkat, dimana hasil belajar yang tidak memenuhi (KKM) dibuktikan dengan perolehan nilai pembuatan boneka dari kain flanel siswa kelas X- IPS setelah dilakukan observasi pertama.

Hasil belajar pada mata pelajaran prakarya kelas X IPS semester I di SMA Sultan Iskandar Muda Medan Tahun ajaran 2013-2014, berdasarkan data yang di peroleh terdapat sekitar $63 \%$ siswa yang dikategorikan tidak tuntas (28 siswa) dari 44 siswa pada mata pelajaran prakarya dengan standar ketuntasan minimal 75. Pada tahun 2014/2015 persentase jumlah yang belum tuntas pada mata pelajaran prakarya adalah $67 \%$ (23 siswa) dari 34 siswa Menurut pengamatan peneliti dilapangan faktor faktor yang paling berpengaruh terhadap rendahnya hasil belajar prakarya siswa SMA Sultan Iskandar Muda adalah keterbatasan guru sebagai pendidik kurang mengoptimalkan dan menvariasikan model model pembelajaran. Akibatnya dalam proses pembelajaran kurang menarik minat siswa dalam mengikuti proses belajar mengajar dengan baik. Menurut Syamsuddin (2004) jika siswa memperoleh nilai dari cukup kebawah dari C sampai D maka minat siswa berada dalam kategori kurang, dalam hal ini tinggi rendahnya minat belajar, dipengaruhi oleh beberapa faktor, antara lain metode dan model pembelajaran yang di terapkan guru harus disesuaikan dengan tujuan pembelajaran.

Terkait dengan hasil penelitian diatas dan permasalahan- permasalahan yang telah ditemukan di SMA Sultan Iskandar Muda Medan, maka untuk mengatasi masalah masalah tersebut peneliti menawarkan strategi model pembelajaran cooperative learning yaitu model pembelajaran Modelling The Way. Setelah peneliti mempelajari model ini, maka peneliti memperkirakan bahwa model ini sangat tepat digunakan untuk meningkatkan kemampuan siswa dalam membuat keterampilan. Model pembelajaran ini juga membuat suasana pembelajaran diruangan kelas menjadi hidup dan situasi ini menyenangkan bagi siswa karena memberi motivasi siswa agar lebih aktif mengikuti pelajaran. Menurut Istarani (2011) Model pembelajaran Modelling The way merupakan model pembelajaran yang memberi kesempatan kepada peserta didik untuk memperaktekan keterampilan spesifik yang dipelajari dikelas untuk demostrasi. Peserta didik diberi waktu untuk menciptakan scenario sendiri dan menentukan bagaimana mereka mengilustrasikan keterampilan dan teknik yang baru saja dijelaskan. Model ini sangat baik jika digunakan untuk mengajarkan keterampilan tertentu.

\section{KAJIAN PUSTAKA}

Penelitian tindakan kelas merupakan interpensi praktik yang di tujukan untuk meningkatkan situasi praktis. Penelitian tindakan kelas yang dikembangkan Arikunto (2011) dalam Manihar Situmorang (2010) sebagai tindakan diberikan yang beorientasi untuk menyelesaikan masalah pribadi atau kelompok yang sudah diketahui. Penelitian tindakan kelas dikarakterisasi secara lingkaran spiral dimulai dari identifikasi 
terhadap masalah, melakukan pengumpulan data secara sistematik, refleksi, analis, pengambilan data melalui perlakuan tindakan, dan diakhiri dengan mengindentifikasi kembali masalah tersebut. Kegiatan Penelitian Tindakan kelas bertujuan untuk membuat usaha berupa tindakan yang dapat mengubah perilaku pengajaran, perilaku murid murid didalam kelas dan mengubah kegiatan pembelajaran didalam kelas.

Kemmis dan Tanggar membagi prosedur penelitian tindakan dalam empat tahap pada satu putaran (siklus), yaitu perencanaan, tindakan, obsevasi, dan refleksi. Model penelitian tindakan tersebut sering diacu oleh para peneliti tindakan.

Proses belajar mengajar atau proses pembelajaran merupakan suatu kegiatan melaksanakan kurikulum suatu lembaga pendidikan, agar dapat mempengaruhi para siswa mencapai tujuan pendidikan yang telah ditetapkan, yaitu mengantar para siswa menuju pada perubahan-perubahan tingkah laku, baik intelektual, moral maupun social agar dapat hidup mandiri sebagai individu dan makhluk sosial. Model pembelajaran akan mengaktifkan pembelajar dalam memberikan tanggapan, umpan balik dan juga mendorong pembelajar untuk melakukan praktik-praktik dengan benar. Dengan demikian model pembelajaran tersebut merupakan pola umum perilaku untuk mencapai tujuan pembelajaran untuk memudahkan mendapatkan informasi, ide, keterampilan, cara berpikir, dan mengekspresikan ide melalui model pembelajaran yang digunakan oleh guru. Model pembelajaran dapat digunakan guru sebagai pedoman dalam merencanakan proses belajar mengajar.

$$
\text { Menurut Agus suprijono }
$$

Modeling the way (membuat contoh praktek) adalah model pembelajaran yang memberi kesempatan kepada siswa untuk mempraktekkan keterampilan spesifik yang dipelajari di kelas melalui demonstrasiModel pembelajaran

Hisyam Zaini dkk ( 2009 : 120) dalam bukunya Model Pembelajaran Aktif mengungkapkan bahwa model Modelling The Way memberi kesempatan kepada siswa untuk mempraktekkan keterampilan spesifiknya di depan kelas melalui demonstrasi. Siswa diberi waktu untuk menciptakan skenario sendiri dan menentukan bagaimana mereka mengilustrasikan keterampilan dan teknik yang baru saja dijelaskan. Model ini akan sangat baik jika digunakan untuk mengajarkan pelajaran yang menuntut keterampilan tertentu.

Langkah pembelajaran Modeling The Way menurut Agus suprijono (2013), terdiri dari (a) Guru membentuk beberapa kelompok. Setiap kelompok terdiri dari 4-5 siswa dengan kemampuan yang berbedabeda baik tingkat kemampuan (tinggi, sedang, dan rendah), (b) Guru menyampaikan kopetensi tentang pembuatan kerajinan boneka dari kain flanel sesuai dengan silabus dan rpp yang telah ada dan menyampaikan tujuan pembelajaran yang ingin di capai dan memberikan motivasi pada siswa, (c) Guru menjelaskan tentang pembuatan boneka panda dari kain dengan membuat Pola boneka boneka besar di papan tulis dan menjelaskan tahap tahap pembuatan dan teknik menjahit boneka, (d) Siswa berdiskusi dengan teman kelompoknya untuk menciptakan skenario tentang tahap tahap pembuatan boneka yang baru dijelaskan guru di depan kelas. Fungsi dari diskusi ialah untuk bertukar pikiran kepada teman untuk mencari solusi tentang pembuatan boneka bagaimana menyatukan boneka dengan ide setiap teman kelompok dan menyatukan ide tersebut, (e) Siswa diberikan beri waktu 5-10 menit untuk berlatih skenario yang baru mereka tentang tahap tahap dan cara menyatukan pola boneka panda,yan dimaksud dengan scenario susunan dari setiap ide anggota kelompok yang digabungkan sebelum mendemonstrasikan di depan kelas, (f) Secara bergiliran tiap kelompok mendemonstrasikan skenario masing-masing. Siswa yang lain diberi kesempatan untuk memberikan feed back pada setiap demonstrasi yang dilakukan. Setelah satu kelompok selesai mendemonstrasikan, kelompok lain dapat memberikan tanggapan atau pertanyaan, (g) Setelah demonstrasi selesai, guru memberikan penjelasan dan penguatan dari 
apa saja yang baru di demostrasikan di depan kelas. Setelah itu siswa menulis kesimpulan bagaimana cara membuat boneka yang benar dan teknik pembuatan yang dijelaskan oleh guru, dan (h) Memberikan test tentang pembuatan boneka dari kain flanel kepada siswa untuk mengetahui tingkat pemahaman terhadap materi yang sudah selesai dipelajari.

\section{METODE PENELITIAN}

Tempat yang penulis jadikan pelaksanaan penelitian tindakan kelas ini di SMA Sultan Iskandar Muda Jln. Amir Hamzah Pekan I Medan Sunggal kelas X IPS. Penelitian tindakan kelas ini dilaksanakan Agustus 2016. Populasi dalam penelitian ini adalah seluruh siswa kelas $\mathrm{X}$ jurusan IPS sekolah Sultan Iskandar Muda dengan jumlah 74 siswa Sampel adalah sebagian dari populasi yang dijadikan subjek penelitian.Teknik sampel adalah purposive sampling yaitu dengan sengaja ditentukan karena siswa kelas X IPS-2 sebanyak 34 orang siswa yang lebih banyak memiliki nilai tidak mencapai KKM. Penelitian tindakan kelas merupakan salah satu jenis penelitian tindakan yang bersifat praktis. Prosedur penelitian ini memiliki empat tahapan dalam tiap siklusnya, yaitu: Perencanaan Tindakan (planning), Pelaksanaan Tidakan (acting), Pengamatan (observing), dan Refleksi (reflecting).

\section{HASIL DAN PEMBAHASAN}

\section{Hasil Penelitian}

Penelitian ini berbentuk penelitian tindakan kelas yang dilakukan di SMA IPS-2 Sultan Iskandar Muda dengan menggunakan model pembelajaran Modelling The Way untuk meningkatkan hasil belajar siswa..

Berdasarkan perolehan nilai pada tahun 2014-2015 banyak siswa yang dikategorikan tidak tuntas pada mata pelajaran prakarya pembuatan boneka dari kain flanel dengan standar ketuntasan minimal 75. Persentase jumlah yang belum tuntas adalah 23 $(67,65 \%)$ dan yang tuntas adalah 11 $(32,35 \%)$. Dapat disimpulkan bahwa hasil belajar siswa membuat boneka dari kain flanel dalam hasil belajar siswa masih dalam nilai persentasi kategori rendah.
Perencanaan tindakan yang telah di sampaikan sebelumnya, peneliti dan Bapak sintong Ekapriasi Situmeang S.Pd berdiskusi untuk menetapkan model pembelajaran Modelling The Way yang akan di dilakukan pada saat penelitian. Pemilihan kelompok dibentuk dengan melihat daftar nilai siswa yang memiliki nilai yang rendah dengan yang tinggi hingga peneliti dan guru bidang studi menetapkan 7 kelompok yang terdiri dari 4 sampai 5 orang perkelompok. Sebelum melakukan penelitian guru dan peneliti.

Pada awal kegiatan guru menentukan kelompok belajar yang telah di tentukan sebelumnya yaitu 7 orang perkelompok yang berjumlah 34 orang siswa, guru menjelaskan bahwa selama pembelajaran teman yang akan membantu rekan-rekan di kelompoknya, dalam satu kelompok terdiri dari 4-5 orang perkelompok yang dipilih dalam kelompok di ambil dari nilai yang terendah dan yang tinggi digabungkan dalam satu kelompok.

Kegiatan inti guru mengawali kegiatan dengan menyampaikan penjelasan mengenai materi pembuatan boneka dari kain flanel, guru menjelaskan dan mendemontasikan cara cara pembuatan boneka dari kain flanel di depan mengunakan pola boneka yang besar agar siswa dapat melihat tahap pembuatan boneka yang disampaikan oleh guru, pada saat bersamaan, siswa-siswa memperhatikan ke papan tulis untuk mendengarkan penjelasaan dari guru. Setelah guru memberikan penjelasan, guru memberikan kesempatan kepada setiap ketua anggota kelompok untuk kedepan dan melihat guru menjelaskan tentang tahap pembuatan boneka dari kain flanel dan memberi penjelasan kepada teman teman angota kelompoknya bagaimana cara menyatukan dan menjahit boneka, kemudian siswa diberi kesempatan 5-10 menit untuk menciptakan scenario tentang tahap tahap pembuatan boneka dan berdiskusi kepada teman disetiap kelompok untuk mereka persentasikan nanti di depan kelas .Pada saat pembelajaran dengan teman kelompok, situasi pembelajaran mengalami perubahan, dari siswa yang hanya diam dan kurang aktif pada saat pembelajaran sebelumnya, menjadi lebih bersemangat, dan antusis siswa-siswa dalam mengerjakan tugas pembuatan boneka dari 
kain flanel. Dalam pelaksanaan ini ada kelompok yang serius dan tekun, ada kelompok yang sangat antusias dalam membimbing rekan kelompoknya, ada juga kelompok yang kurang aktif dalam pelaksaan pembelajaran. Setelah itu guru meminta kepada siswa untuk mempersentasikan hasil scenario setiap angota kelompok tentang tahap tahap pembuatan boneka bersama teman kelompoknya dan teman yang lain menanggapi hasil diskusi mereka tentang pembuatan boneka di mulai dari kelompok yang pertama sampai kelompok yang terakhir, setelah itu guru memberi penghargaan kepada kelompok yang mempersentasikan hasil skenario pembuatan boneka selesai dengan baik dan menyimpulkan hasil persentasi yang mereka tampilkan didepan kelas.

Pada akhir kegiatan guru meminta siswa untuk menyampaikan pendapatnya mengenai pembelajaran dengan menggunakan model pembelajaran Modelling The way yang telah dilakukan. Guru menutup pelajaran, menyampaikan jika pada pembelajaran ini belum memenuhi pencapaian standart ketuntasan hasil belajar maka akan dilakukan pertemuan berikutnya dengan aktivitas dan hasil belajar yang sama.

\section{a. Deskripsi Pengamatan \\ 1) Pengamatan Dosen}

Pada pelaksanaan siklus I, observasi terhadap hasil belajar membuat boneka dari kain flanel menggunakan Model Pembelajaran Modelling The way dilakukan oleh 5 orang pengamat yaitu dan 2 guru SMA yaitu Bapak Sintong Ekapriasi Situmeang S.Pd, dan Ibu Gracia S.Pd,Selaku guru bidang studi Prakarya dan 3 orang .

Apabila hasil belajar siswa dibawah Standar Kriteria Ketuntasan Minimum (KKM) yaitu 75 dan ketuntasan tidak mencapai $75 \%$ dari jumlah siswa maka dilaksanakan siklus II dengan model pembelajaran Modelling The Way.. Pengamatan dilakukan terhadap hasil belajar membuat boneka dari kain flanel.

Dari hasil pengamatan dapat diketahui uji kesepakatan pengamat yang dapat disajikan dalam perhitungan pada lampiran 2 dengan hasil $F_{\text {hitung }}=0,0089$ selanjutnya di bandingkan dengan harga $\mathrm{F}_{\text {tabel }}$ dengan taraf signifikan 5\%=3,44. Dan ternyata $\mathrm{F}_{\text {hitung }}$ lebih kecil dari harga $\mathrm{F}_{\text {tabel }} \mathrm{l}$ yaitu $0.0089<3,44$. Dengan demikian dapat disimpulkan bahwa tidak terdapat perbedaan yang signifikan antara hasil dari kelima pengamat serta memiliki pemahaman yang sama dalam menilai penelitian ini.

Data hasil penelitian terdiri hasil dari kelima pengamat yaitu 3 Orang Dosen pengamat dari bidang studi PKK yang ahli dibidangnya dan 2 orang guru bidang Studi prakarya membuat boneka dari kain flanel. Hasil pengamatan berfungsi untuk mengetahui sejauh mana tingkat pengetahuan siswa terhadap materi yang akan dipelajari dan untuk mengetahui peningkatan hasil belajar setelah diterapkannya model pembelajaran Modelling The Way.

Dari hasil penelitian terhadap sampel 34 orang diperoleh deskripsi data dimana nilai tertinggi yaitu 93,44 , nilai terendah adalah 28,13 dengan mean adalah 18,29 dan standart deviasinya adalah 81,53.

Berdasarkan tabel diatas maka dapat dilihat persentase ketuntasan siswa sebagai berikut:

Tabel 2 Persentasi Ketuntasan Nilai Siswa Membuat Boneka

\begin{tabular}{|l|l|l|l|}
\hline No & Keterangan & $\begin{array}{l}\text { Jumlah } \\
\text { Siswa }\end{array}$ & $\begin{array}{l}\text { Persentase } \\
\%\end{array}$ \\
\hline 1 & Tuntas & $\begin{array}{l}\text { 29 orang } \\
5 \text { orang }\end{array}$ & $\begin{array}{l}85,30 \% \\
14,70 \%\end{array}$ \\
\hline & Tidak Tuntas & Jumlah & $100 \%$ \\
\hline
\end{tabular}

Pada siklus I hasil belajar siswa yang tuntas mencapai $85,30 \%$ (29 orang) dari jumlah siswa sebanyak 34 orang. Dan siswa yang tidak tuntas mencapai $14,70 \%$ (5 orang) dari seluruh siswa. Hal ini apabila dibandingkan dengan hasil belajar siswa sebelum menggunakan model pembelajaran Modelling The Way dapat disimpulkan bahwa hasil belajar pada mata pelajaran prakarya kelas X IPS semester I di SMA 
Sultan Iskandar Muda Medan Tahun ajaran 2013-2014, berdasarkan data yang di peroleh terdapat sekitar $63 \%$ Siswa yang dikategorikan tidak tuntas pada mata pelajaran prakarya dengan standar kopetensi dengan standar ketuntasan minimal 75. Pada tahun 2014-2015 bahwa persentase jumlah yang belum tuntas pada mata pelajaran prakarya adalah $67 \%$. Hasil belajar yang dicapai siswa belum maksimal karena belum mencapai Kriteria Ketuntasan Minimal (KKM) yakni $75 \%$ yaitu dengan menggunakan model pembelajaran ceramah dan demonstrasi. Setelah dilaksanakan pembelajaran dengan menggunakan model pembelajaran modeling the way diperoleh persentase ketuntasan siswa pada siklus I sebesar $85,30 \%$ dari jumlah siswa sebanyak 34 orang. Sehingga dapat dilihat peningkatan persentase ketuntasan sebesar 52,30\% dari hasil sebelum menggunakan model pembelajaran Modeling The Way. Sehingga tidak perlu dilakukan siklus ke II karena hasil belajar siswa karena Secara klasikal sekurang kurangnya $75 \%$ siswa memperoleh nilai $\geq 75$ sesuai dengan kriteria ketuntasan minimal (KKM).

\section{2) Hasil Observasi Aktivitas Siswa}

Pengamatan aktivitas ini dilakukan pada setiap pertemuan yaitu pada saat pelaksanaan siklus I. Hasil observasi aktivitas belajar siswa dapat dilihat pada tabel berikut:

Tabel 3 Peningkatan Aktivitas Siswa

\begin{tabular}{|l|c|c|}
\hline $\begin{array}{l}\text { Kreteria } \\
\text { Aktivitas }\end{array}$ & $\begin{array}{l}\text { Jumlah } \\
\text { Siswa }\end{array}$ & Persentase\% \\
\cline { 2 - 3 } & SIKLUS I & Aktivitas Belajar \\
\hline Sangat Aktif & 8 & $23,52 \%$ \\
Aktif & 18 & $51,42 \%$ \\
Cukup Aktif & 6 & $17,14 \%$ \\
Kurang Aktif & 2 & $5,71 \%$ \\
\hline
\end{tabular}

Sumber: Lembar observasi aktivitas siswa Kriteria Kriteria Penelitian Aktivitas :

28 - 32 Sangat Aktif (SA)

$23-27$ Aktif (A)

$18-22$ Cukup Aktif (CA)

13 - 17 Kurang Aktif (KA)

$8-12$ Tidak Aktif (TA)
Refleksi dilakukan untuk mengetahui sejauh mana tingkat keberhasil dari penerapan model pembelajaran Modeling The Way, kemudian mnegetahui hasil belajar pada siklus I, menganalisis kendala kendala yang dihadapi pada pembelajaran sebellumnya. Berdasarkan hasil pengamatan dan evaluasi yang telah dikalkukan, diperoleh data bahawa pada siklus 1 , siswa yang memperoleh nilai $\geq \mathrm{KKM}$ adalah 85,30 $\%$ dari 34 orang siswa.

Hasil refleksi pada siklus 1 merupakan data yang diinginkan untuk mengambil keputusan Dari hasil penelitian dan tim pengamat setelah dilakukan pembelajaran pada siklus I, diperoleh adanya peningkatan hasil belajar siswa kelas X SMA Sultan Iskandar Muda pada sub pokok bahasan membuat boneka dari kain flanel dengan menerapkan model pembelajaran Modelling the way, dengan ketuntasan belajar 85,30\%. Hal ini menyatakan telah mencapai ketuntasan secara klasikal sehingga tidak perlu lagi dilanjutkan ke siklus berikutnya.

\section{Pembahasan Penelitian}

Hasil pengamatan selama satu siklus memberikan gambaran bahwa hasil belajar siswa dalam mendengarkan penjelasan guru, mampu mempraktekkan langsung dalam pembuatan boneka merupakan kegiatan paling dominan dilakukan oleh siswa disepanjang siklus tersebut. Persentasi yang rendah yang jarang dilakukan siswa dalam proses pembelajaran dikelas adalah mendengarkan penjelasan guru, mengajukan pendapat/ berhipotesis dan juga bertanya. Oleh karena itu,perbaikan pembelajaran dilakukan melalui penelitian tindakan kelas ini bertujuan untuk meningkatkan hasil belajar lainnya pada diri siswa. Peningkatan ini merupakan selisih antara klasikal hasil belajar sebelum menggunakan Modelling The Way dengan siklus I yang telah menggunakan moel pembelajaran Modelling The Way sehingga terjadi peningkatan hasil belajar siswa. Hal ini sejalan dengan penemuan dari Nixon Simangunsong (2015) menunjukkan Model Pembelajaran Modelling The Way Pada Siswa Kelas X SMK Negeri 2 Medan bahwa pembelajaran menggunakan Model Modelling The way dengan optimalisasi 
penggunaan media juga dapat meningkatkan hasil belajar siswa. Dari tes evaluasi hasil belajar siswa terjadi peningkatan dimana 26 siswa $(74,20 \%)$ yang tuntas belajar pada siklus I menjadi 29 siswa $(82,8 \%)$ pada siklus II dimana terjadi peningkatan $8,6 \%$, berarti bahwa telah tercapai batas tuntas indikator yang ditetapkan secara klasikal yaitu $80 \%$ siswa memperoleh nilai $\geq 75$, hal ini dikarenakan siswa mampu aktif dalam setiap proses pembelajran dan sangat cocok bagi siswa yang mengikuti pelajaran praktek sehingga model pembelajaran ini efektif untuk meningkatkan hasil belajar siswa. Model pembelajaran Modelling The Way memberikan kesempatan kepada siswa untuk terlibat aktif seperti menjawab pertanyaan, melakukan pengamatan yang selanjutnya dipersentasikan, serta membuat siswa mampu mengembangkan kemampuan berfikirnya.

\section{KESIMPULAN}

Berdasarkan hasil penelitian tindakan kelas, dapat disimpulkan bahwa:

1. Dalam kegiatan belajar mengajar, guru diharapkan menerapkan model pembelajaran Modeling The Way sebagai model pembelajaran alternatif dalam memberikan materi dalam pelajaran prakarya dan kewirausaan membuat boneka dari kain flanel untuk meningkatkan hasil belajar siswa.

2. Diharapkan guru mengunakan model pembelajaran yang sesuaiu ntuk meningkatkan kemampuan mereka dalam pelajaran pembuatan boneka dari kain flanel, meningkatkan minat belajar siswa dalam belajar, dan meningkatkan motivasi bagi diri siswa untuk berkreatifitas

3. Guru hendaknya dapat menerapkan model pembelajaran Modelling The Way atau yang memiliki mata pelajaran dengan karakter yang sama dan selalu berusaha menggali ide yang bersifat kreatif dan inovatif, sehingga kegiatan yang dilakukan akan lebih bermakna dan dapat meningkatkan semangat siswa.

4. Keberhasilan pembelajaran dikelas tentunya tidak terlepas dari tersedianya fasilitas yang menggunakan kegiatan belajar mengajar. Oleh karena itu diharapkan peran semua peserta didik untuk melengkapinya.

\section{DAFTAR PUSTAKA}

Agus Suprijono. (2013). Cooperative Learning (Teori dan aplikasi Paikem). Jakarta: Pustaka Pelajar.

Annurrahman. (2009). Belajar Dan Pembelajaran. Bandung: Alfabeta.

Arikunto, Suharsimi. (1987). Strategi Proses Blejara Mengajar. Jakarta: PT. Bumi Aksara.

Arikunto, Suharsimi. (2004). Prosedur Penelitian Suatu Pendekatan Praktik. . Jakarta: PT. Bumi Aksara.

Arikunto. (2010). Prosedur Penelitian Suatu Pendekatan Praktik. Jakarta: Rineka Cipta.

Denelis. (2011). Membuat Boneka dari Kain Flanel. Bandung: Gramedia

Depdikbud. (2002). Model-Model Pembelajaran Dirjen Pendidikan dasar dan Menengah Depertemen Pendidikan Nasional.Jakarta: PGSM.

Hamalik. (2006). Proses belajar mengajar. Bandung : Bumi Aksara.

Hisyam Zaini. (2009). Model Pembelajaran Aktif. Bandung: Fajar Mulia

Istarani. (2011). 58 Model - Model Pembelajaran. Medan: Media Persada

Ngalium, (2012). Strategi dan Model Pembelajaran.Banjarmasin :Aswana Pressindo

Nixon, (2015). Upaya Meningkatkan Aktivitas Dan Hasil Belajar Siswa Mata Pelajaran Menggambar Teknik Dengan Modelling The Way Pada Siswa Kelas X SMK Negeri 2 Medan. Universitas negeri Medan.

Purwanto, Ngalim. (2010). Evaluasi Pengajaran. Bandung: PT Remaja Rosdakarya.

Rusman. (2012). Model - Model Pembelajaran Mengembangkan 
Profesional Guru. Jakarta: Rajawali Pers.

Sudjana, Nana. ( 2009). Penilaian Hasil Belajar Mengajar. Bandung: PT Remaja Rosdakarya

Sukardi, H.M. (2012). Metode Penelitian Pendidikan Tindakan Kelas.Jakarta: PT. Bumi Aksara

Tim Dosen. (2014). Psikologi Pendidikan.Medan: PPs Unimed

Uno, Hamzah. (2014). Model Pembelajran: Jakarta: BMT Nurul Jannah.

Wena Made. (2008). Strategi Pembelajaran Inovatif. Malang: Bumi Aksara.

Slameto. (2010). Belajar \& factor-faktor mempengaruhi. Jakarta: Rineka Cipta

Istarani. (2012). Kumpulan 39 Metode Pembelajaran Medan:Iscom Medan

Samsu Sumadayo. (2013). Penelitian Tindakan Kelas. Yogyakarta:Graha Ilmu

Nana Sudjana. (2009). Penilaian Hasil Proses Belajar Mengajar. Bandung :RemajaRosdakarya

Sani (2013). Meningkatkan Profesionalisme Guru Melalui Penelitian Tindakan Kelas. Bandung: Cipta Pustaka Media Perintis

Sugiono. (2010). Metoda Penelitian Pendidikan Kuantitatif, Kualitatif Dan $R \& D$. Bandung: Alfabeta

Sanjaya Wina( 2006) pembelajaran kooperatif, Jakarta: Prenada Premium Grup. 